\title{
EVALUATION OF CUSTOMER VALUE BY BUILDING OWNERS IN THE CONSTRUCTION PROCESS
}

\author{
Janosch Dlouhy ${ }^{1}$, Stephan Wans ${ }^{2}$ and Shervin Haghsheno ${ }^{3}$
}

\begin{abstract}
Lean Construction is mainly linked to the creation of value for the client/customer. Rarely do construction publications address methods or models to understand, determine, or define the core concept of this value. This paper gives an overview of existing approaches outside the construction sector and their applicability to the construction process is analyzed. The Means-End Model - widely used in scientific customer studies outside the Lean Construction context - is then investigated further and the Customer Value in the construction process is structured according to it.
\end{abstract}

\section{KEYWORDS}

Value, Customer, Client, Building Owner, Value Management, Means-End Model.

\section{INTRODUCTION}

Customer Value is a fundamental concept in Lean Thinking. Simultaneously, understanding Customer Value is the first and foremost Lean Principle to which all others (value chain, pull, flow and continuous process improvement) should align) (Haghsheno et al.2015. It is therefore important to define the term Customer Value and to understand what factors influence it. This is especially true for the utilization of Lean Principles in the construction industry, since construction projects are inherently customer driven (Fadhil Dulaimi 2005).

Contrary to this stands the existence of many non-value-adding activities in most construction projects (Bølviken and Koskela 2016). For this reason, it seems as if

1 Research Fellow, Karlsruhe Institute of Technology, Germany, +49-721-608-42168, janosch.dlouhy@kit.edu

2 M.Sc. Student, Karlsruhe Institute of Technology, Germany, +49-163-249-7705, stephan.wans@alumni.kit.edu

3 Professor, Karlsruhe Institute of Technology, Germany, +49-721-608-42646, shervin.haghsheno@kit.edu 
Customer Value is not given enough attention in construction practice. In addition, Lean Construction theory states that its biggest weakness lies in understanding the nature of Customer Value (Bertelsen 2004). Among the reasons for this, as identified by other authors, are:

- A commonly accepted and used definition of Customer Value does not exist (Drevland and Lohne 2015).

- Customer Value is an established field of interest in market and business research, but the results are barely used in the Lean Construction community (Drevland and Lohne 2015).

- Most IGLC publications respect the value of the building for the customer. The construction process is the value generator in this context. Since construction projects last for a longer period, the participants also have a rightful interest in the organization of the processes in that project) (Emmitt 2005; Binninger et al.2017). Only few authors include this perspective in Customer Value research for Lean Construction.

These facts show the need for a commonly accepted definition of Customer Valueand a better understanding of the influencing factors. With the goal to develop an approach to describe those factors, a literature study has been conducted. This paper then presents an approach for defining the Customer Value based on a Means-End Model.

\section{CURRENT APPROACHHES TO CUSTOMER VALUE IN CONSTRUCTION}

The term "Customer Value" implies two questions: 'Who is the customer?' and 'what is value?' Answering these questions is essential for establishing a better understanding of Customer Value. Depending on the scientific perspective, these questions might be answered differently.

\section{THE BUILDING OWNER AS THE CENTRAL CUSTOMER IN THE CONSTRUCTION PROCESS}

There are many participants in the construction process who can be the customer. To define Customer Value, it is therefore important to clarify for whom the value is investigated. Figure 1 illustrates this by showing a possible structure of a construction project in which a company is financing and using the building for itself.

While many customer relations are apparent in the construction process, one that is particularly important is that of the building owner to the other project participants. Since the building owner has big impact on the construction process due to his rights and duties, he is a central figure. While the end user is mostly interested in the usage of the outcome (building) of that process, the owner itself does also care about the construction, since it is his financial and temporal investment that allows the realization of the project. Sometimes (as seen in Figure 1) the building owner and the end user are even part of the same company or are represented by the same person, which gives him an even bigger importance. Also, in general language usage, the building owner is meant when talking 
about the customer or client. The building owner is therefore the target of the following analysis in this paper.

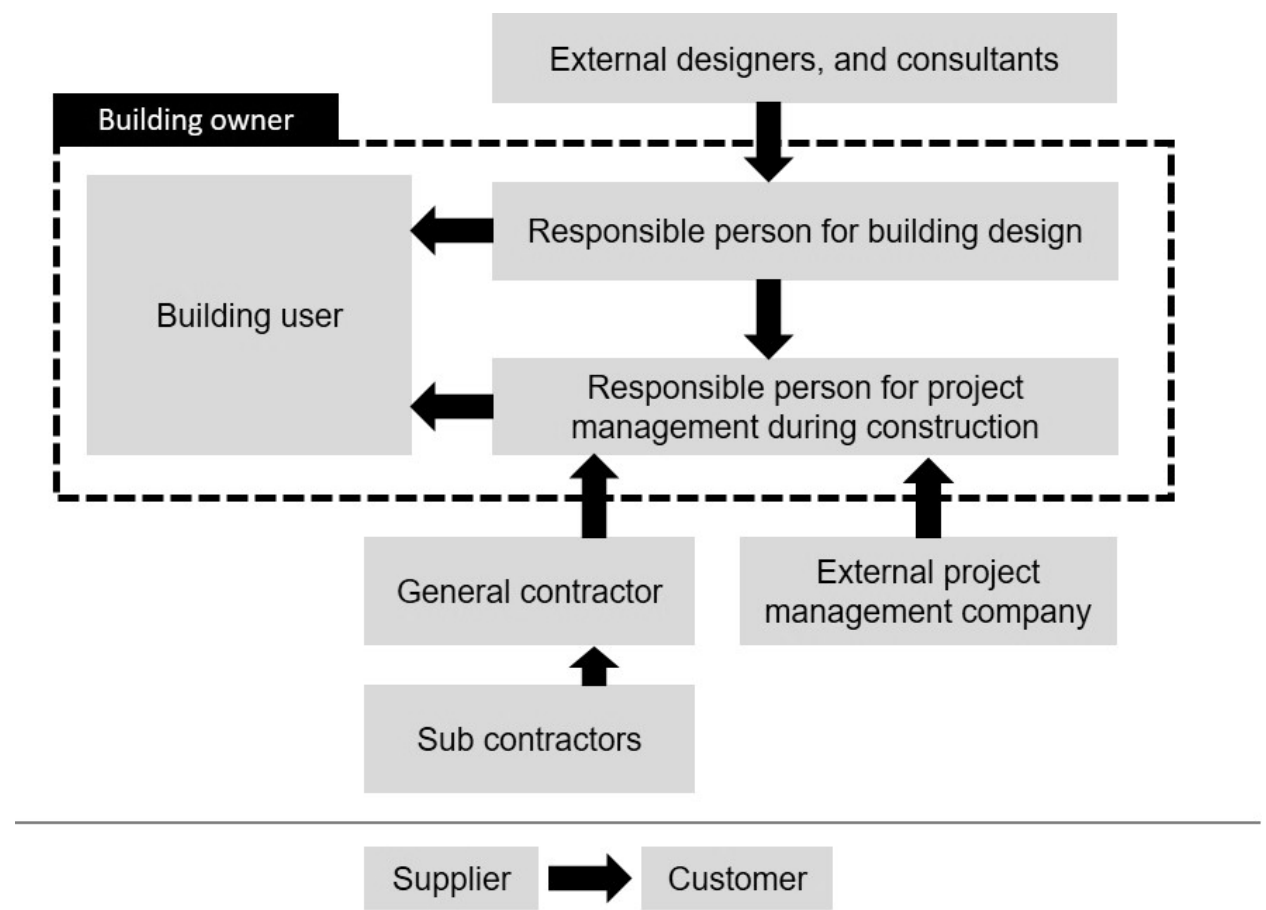

Figure 1: Possible customer relationships (arrows) in a company's construction project, where the supplier is delivering information, services or products.

\section{THE VALUE OF THE BUILDING OWNER IN THE CONSTRUCTION PROCESS}

The question "what the customer's value is" requires a wholistic answer. Many authors of various specialist fields deal with finding this answer. The result is a multitude of definitions and models. They all see Customer Value as something that is linked to the customer's wants or needs and they can be sorted into three categories: Component, Relationship and Means-End Models (Salem Khalifa 2004). In the following it will be analyzed whether these models are applicable to Customer Value in the construction process.

The Basis for this analysis is the idea of a process oriented customer value. Investigations must therefore consider, that this does not only concern a physical product, but also a process. This process has the goal of achieving a product (building). Additionally, business to customer (B2C) and business to business (B2B) relationships are possible. The resultant project organizational structures are noticeably different, and it is assumed the decision-making processes for business customers are more rational than those of private customers (Gerth 2015).

Component Models are the simplest models. They describe the various component parts, which may have a greater or lesser effect on Customer Value depending on the product and customer. Well known models include those from Kaufmann (Salem Khalifa 2004), Sheth (1991) and Holbrook (Gallarza and Gil Saura 2006). They provide good 
descriptions of the influential factors and how they differ from one another and they are well suited to evaluate product attributes (Khalifa 2004). As they do not give any subjective evaluations, they are also suitable for business relationships characterized by rational decisions.

They, however, do not assess the interaction between components or between customer and supplier. They are therefore less suited to assess Customer Value in interactive processes. While some categories can be applied to the construction process, the result is highly simplified and only few interrelationships are considered.

Relationship models (also "value exchange models") place different components of value in relation to one another to analyze their effect on the customer. They have the common feature of comparing and weighing up advantages and disadvantages to the customer. For this they use conceptual pairs such as "benefits received - sacrifices made" (Salem Khalifa, 2004), "perceived advantages - perceived disadvantages" (Huber et al. 2001) or "positive consequences - negative consequences" (Woodruff 1997). Additional approaches are defined by Dodds (et al. 1991), Gale and Wood (1994) and Woodruff und Gardial (1996).

Relationship models are more complex than Component models and include many relationships that go beyond the sales process. The models attempt to describe these as rationally as possible and are therefore also applicable for B2B relationships. A weakness of Relationship Models is that they do not explain why particular attributes are evaluated as positive or negative, or important and unimportant by the customer as they do not consider the underlying goals of the customer. Additionally, Relationship Models are static. They compare positive and negative attributes at a point in time, meaning analysis of dynamic relationships such as those within construction processes are difficult to assess. This means that Relationship models have only limited applicability for processes.

Means-end models are a third way of discussing Customer Value. These seek to determine a connection between the attributes of a product or service (Means) and the goals of the customer (Ends). They do describe why certain attributes are of value to the customer and in relation to which goal. They are the most used approaches for describing Customer Value in literature on consumer behavior (Salem Khalifa 2004). One of the most well-known of this type of model is that of Woodruff (1997).

Means-end models explain how the customer values the attributes of a product or process. Hereby they include the goals of the customer. They explicitly address the consequences of a product or process caused during their use. Therefore, dynamic relationships are easier to describe than in the Relationship Models. Means-End Models rely less on specific attributes such as price and quality and thereby have greater flexibility in application. Due to their abstract nature, Means-End Models can be applied in many ways. However, some areas such as weighing up advantages and disadvantages are nonetheless better described by relationship models. The primary disadvantage is that the models do not show how many disadvantages a customer is willing to accept, and if these can be balanced out by the advantages.

Conclusion: analysis of the models shows, that the Component Model gives an overly simplified image of Customer Value and is too product-oriented. The Relationship Models are also not suited to processes due to their static approach and their inability to 
describe why certain factors are important to the customer. For this reason, the approach of the Means-End Models is best suited as the basis for a Customer Value Model. They are abstract enough to describe the complex execution of construction processes. However, to create a system based on the Means-End Models, the approach of the model must be adapted to suit the construction industry.

\section{DETAILING THE MEANS-END MODEL FOR THE CONSTRCUTION PROCESS}

The Means-End Model described above is made up of attributes and their resultant consequences for achieving the goals of the customer. Applying this to the construction process and customer, results in the following levels of hierarchy: "Attributes of the Construction Process", "Consequences of the Construction Process Attribute" and "Goals of the Customer in the Construction Process" (see Figure 2). These will be investigated in greater detail in the following paragraphs".

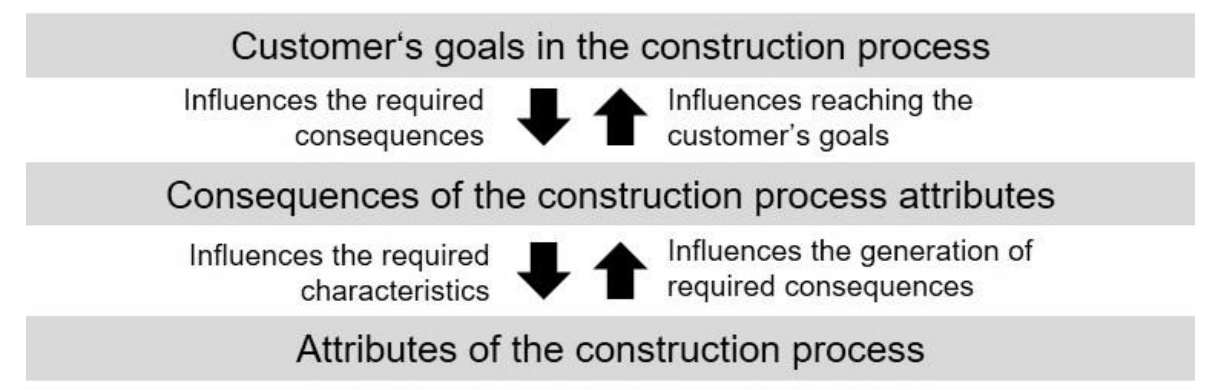

Figure 2: Concept of a Means-End Model for the Construction Process

\section{Analysis of Customer Goals in the Construction Process}

Aside from completing the building, the general customer goals (time, cost, quality; as well as simple and efficient consideration of customer rights and obligations (Wollensak 2013)), are the main motives of the customer. Requirements of the construction project and its participants result from these. Additional requirements do not lie in the customer's core interests, but rather are caused by environmental factors. These must be accounted for to prevent negative consequences. The resultant requirements, however, are made on his or her behalf. Together these customer demands and external conditions form the requirements whose fulfilment is the goal of the construction process (Kamara et al. 2000) (see Figure 3). 


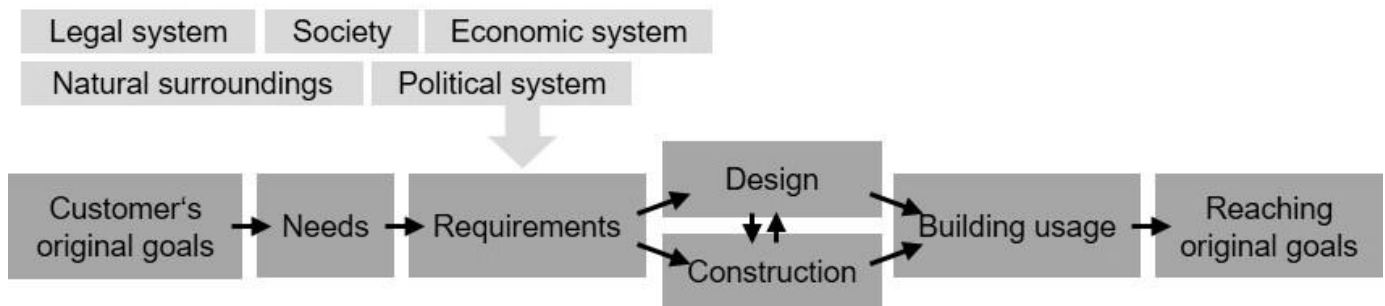

Figure 3: Influence of demands and conditions on requirements of a construction process

ANALYSIS OF CONSEQUENCES OF THE CONSTRUCTION PROCESS ATTRIBUTES

The customer's goals in the construction process are influenced by the consequences of the process characteristics. One could also call these the state of the construction process. Analyzation of the customer's goals and interviews with many leading responsible project managers in a worldwide operating enterprise resulted in four relevant consequence-categories: information, project structure, team and construction process. The detailed items in these categories can be found in Figure 4 and might be complemented in the future.

\section{ANALYSIS OF CONSTRUCTION PROCESS ATTRIBUTES}

The attributes are the attributes of the construction process. The characteristics that are of interestdiffer depending on the perspective on the construction process and the investigated topics. For example, a characteristic could describe the type of construction process, materials, type and number of workers, reporting and meeting requirements, type of logistics etc.

\section{A MEANS-END MODEL FOR THE CUSTOMER VALUE IN THE CONSTRUCTION PROCESS}

Using the goals, consequences and attributes that were analyzed before, the Means-End Model (Figure 2) can be detailed as shown in figure 4.

The system has three main principles: (1) The factors influencing Customer Value are the customer's goals in the construction process, the attributes of the construction process and the consequences of those. (2) The system gives examples of how these goals, consequences and attributes appear in detail and categorize them (3) Customer Value is the sum of its attributes and consequences seen by the customer as contributing to reaching his or her goals in the construction process. 


\begin{tabular}{|c|c|c|c|c|}
\hline \multicolumn{5}{|c|}{$\begin{array}{l}\text { GOALS } \\
\text { of the customer in the construction process }\end{array}$} \\
\hline \multicolumn{2}{|c|}{ Fulfillment of NEEDS } & \multicolumn{3}{|c|}{ Fulfillment of CONDITIONS } \\
\hline Hard needs & Soft needs & \multicolumn{2}{|c|}{ Duties } & Surroundings \\
\hline $\begin{array}{l}\text { Cost } \\
\text { Schedule } \\
\text { Quality }\end{array}$ & $\begin{array}{l}\text { Flexible } \\
\text { decision making } \\
\text { Cooperation } \\
\text { Communication }\end{array}$ & \multicolumn{2}{|c|}{$\begin{array}{l}\text { Controlling } \\
\text { Coordination } \\
\text { Documentation } \\
\text { Decision making } \\
\text { Resource provision }\end{array}$} & $\begin{array}{l}\text { Environment } \\
\text { Society } \\
\text { Market/economics } \\
\text { Political situation } \\
\text { Laws and orders }\end{array}$ \\
\hline \multirow{2}{*}{\multicolumn{5}{|c|}{ Customer Value = $\begin{array}{l}\text { Sum of all attributes and consequences that the } \\
\text { customer evaluates as benefical for his goals }\end{array}$}} \\
\hline & & & & \\
\hline INFORMATION & \multicolumn{2}{|l|}{$\begin{array}{l}\text { PROJEKT- } \\
\text { STRUCTURE }\end{array}$} & TEAM & $\begin{array}{l}\text { CONSTRUCTION } \\
\text { PROCESS }\end{array}$ \\
\hline $\begin{array}{l}\text { Transparency } \\
\text { Efective and } \\
\text { efficient } \\
\text { communication } \\
\text { In-time decision } \\
\text { making }\end{array}$ & \multicolumn{2}{|c|}{$\begin{array}{l}\text { Standards } \\
\text { Clear } \\
\text { Responsibilities } \\
\text { Learning effects/ } \\
\text { continuous } \\
\text { improvements }\end{array}$} & $\begin{array}{l}\text { Trust } \\
\text { Commitment } \\
\text { and motivation }\end{array}$ & $\begin{array}{l}\text { Continuous } \\
\text { progress } \\
\text { Predictability } \\
\text { Flexible processes } \\
\text { and product } \\
\text { Security, order, } \\
\text { cleanliness } \\
\text { area prioritization }\end{array}$ \\
\hline \multicolumn{5}{|c|}{$\begin{array}{l}\text { ATTRIBUTES } \\
\text { of the construction process }\end{array}$} \\
\hline
\end{tabular}

Figure 4: Detailed Means-End Model for the construction process

\section{FINDINGS}

The analysis of existing models for Customer Value showed that a Means-End Model is capable of structuring Customer Value in the construction process. The result is a process-oriented model of Customer Value, which to date has been rarely investigated in the context of construction projects. The Means-End approach shows, that Customer 
Value is not a characteristic of the customer and is not equal to ethical or personal values. Similarly, Customer Value cannot be considered equivalent to requirements, wishes, goals or demands. Rather, Customer Value is the sum of the attributes and consequences which the customer has evaluated as useful for achieving his or her goals. A conclusion of the system is therefore:

\section{Fulfilling customer requirements $=$ Value Creation but: Customer requirements $\neq$ Customer Value}

Moreover, the system provides a framework for categorizing many other terms that play an important role in the construction industry. In this way, for example, the significance of trust (McDermott et al. 2005) and cooperation (Phua and Rowlinson 2004) in the construction process have long been known.

The Means-End Model defined by Woodruff not only conceptualizes the customer value, it also serves as a basis for a definition of this term (Woodruff 1996). This approach and definition, can be adapted slightly to include the construction process as well:

"Customer Value is the result of a customer's perceived judgement of those product or process attributes, attribute performances, and consequences arising from those that facilitate (or block) achieving the customer's goals and purposes in a product's use situation or in a process."

According to this, it is not goals that define Customer Value, but rather the attributes, attribute performances, and consequences that lead to achieving the goals of the customer.

\section{CONCLUSION \& DISCUSSION}

The basis of this research is the emergence of customer-oriented management approaches in the construction industry. There are currently significant weaknesses in how this topic is dealt with (Bertelsen 2004). The model developed in this paper provides an approach to provide a deeper understanding of Customer Value. Using existing considerations for process-oriented Customer Value (Emmitt, 2005; Binningeret al. 2017) it extends the currently predominant product-oriented perspective on Customer Value. Furthermore, it uses the Means-End approach - widely used in scientific customer studies outside the Lean Construction context - as a basis for determining Customer Value (Salem Khalifa 2004). Making it possible to incorporate existing knowledge from other specialist fields.

While many project participants can be labelled as the customer, in this case the building owner is considered as the central figure in the construction process. Further research is required to understand to what extend additional goals and consequences influence Customer Value and what priorities are set by other customers in the construction process. Moreover, the question remains of how suitable Means-End Models are for describing product-oriented Customer Value (e.g. buildings) and if additional goals, consequences and attributes need to be considered.

The model should also serve as a basis for targeted and consistent use of terminology for describing Customer Value. Currently it is most frequently defined as related to fulfilling requirements (Koskela 2000). Other authors discuss fulfilling demands and 
reaching strategic goals (Haddadi et al. 2016) or define Customer Value as "what the customer wants" (Orrechia and Howell 1999). For a common understanding of Customer Value these inconsistencies must be minimized in future.

\section{REFERENCES}

Bertelsen, Sven; Koskela, Lauri (2004), „Construction beyond lean: a new understanding of construction management". Proceedings of the 12th annual conference in the International Group for Lean Construction

Bølviken, Trond; Koskela, Lauri (2016), „Why Hasn't Waste Reduction Conquered Construction?“. 24th Annual Conference of the International Group for Lean Construction. Boston, USA, 3-12.

Dodds, William B.; Monroe, Kent B.; Grewal, Dhruv (1991), „Effects of Price Brand and Store Information on Buyers Product Evaluations“. Journal of Marketing Research, 307-319.

Drevland, Frode; Lohne, Jardar (2015), „Nine Tenets on the Nature of Value“. 23rd Annual Conference of the International Group for Lean Construction, Perth, Australia, 475-485. Binninger, Marco; Dlouhy, Janosch; Haghsheno, Shervin (2017), „Technical Takt Planning andTakt Control in Construction." 25 th Annual Conference of the International Group for Lean Construction. Heraklion, Greece, 605-612.

Dodds, William B.; Monroe, Kent B.; Grewal, Dhruv (1991), „Effects of Price Brand and Store Information on Buyers Product Evaluations“. Journal of Marketing Research. 307-319.

Emmitt, Stephen; Sander, Dag; Christoffersen, Anders Kirk (2005), „The Value Universe: Defining a Value Based Approach to Lean Construction“. 13th International Group for Lean Construction Conference: Proceedings.,57.

FadhilDulaimi, Mohammed (2005), „The challenge of customer orientation in the construction industry“.Construction Innovation, 3-12. Phua,Florence; Rowlinson,Steve (2004), „How important is cooperation to construction project success? A grounded empirical quantification“. Engineering, Construction and Architectural Management, 45-54.

Gale, Bradley; Wood, Robert Chapman (1994), Managing Customer Value: Creating Quality and Service That Customers Can See. Simon and Schuster.

Gallarza, Martina G.; Gil Saura, Irene (2006), „Value dimensions, perceived value, satisfaction and loyalty: an investigation of university students' travel behaviour".TourismManagement. 437-452.

Gerth, Norbert (2015), „Zum Kaufverhalten von Privat- und Geschäftskunden“. ITMarketing. Springer Gabler, Berlin, Heidelberg, 67-127.

Haddadi, Amin; Johansen, Agnar; Andersen, Bjørn (2016), „A Conceptual Framework to Enhance Value Creation in Construction Projects“. Procedia Computer Sci.100, 565573.

Haghsheno, Shervin; Binninger, Marco; Dlouhy, Janosch (2015), „Wertschöpfungsorientierte Planung und Realisierung von Bauvorhaben durch Lean Construction“. VDI Bautechnik. (Jahresausgabe 2015/2016), 140-145. 
Huber, Frank; Herrmann, Andreas; Morgan, Robert E. (2001), „Gaining competitive advantage through customer value oriented management“. J Consum Mark, 18 p. 4153.

Kamara.;Anumba; Evbuomwan, (2000), „Establishing and processing client requirements - a key aspect of concurrent engineering in construction“. Engineering Construction and Architectural Management. 7, 15-28.

Klevers, Thomas (2007), Wertstrom-Mapping und Wertstrom-Design: Verschwendungerkennen - Wertschöpfungsteigern.

Koskela, Lauri (2000), „An exploration towards a production theory and its application to construction“. VTT Technical Research Centre of Finland.

Orrechia, Federico; Howell, Gregory A. (1999), „Reflections on Money and Lean Construction“. Proceedings IGLC, 253. McDermott; Khalfan; Swan (2005), „Trust in construction projects“. Journal of Financial Management of Property and Construction. 10, 19-32.

Salem Khalifa, Azaddin (2004), „Customer value: a review of recent literature and an integrative configuration“. Management Decision. 42, 645-666.

Sheth, Jagdish; Newman, Bruce I. (1991), „Why we buy what we buy: A theory of consumption values“. Journal of Business Research. 22, 159-170.

Wollensak, Julia (2013), Entscheidungsprozesse und Aufgaben eines Bauherrn. Univ. Stuttgart, Institutfür Baubetriebslehre.

Woodruff, Robert (1997), „Customer value: The next source for competitive advantage“. Journal of the Academy of Marketing Science. 25, 139.

Woodruff, Robert; Gardial, Sarah (1996), Know your customer: New approaches to understanding customer value and satisfaction. Wiley. 